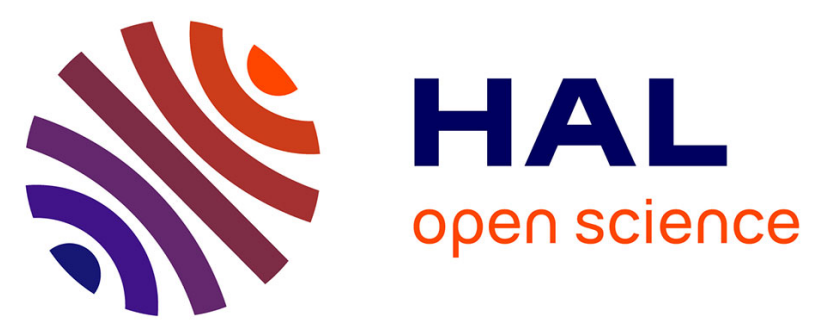

\title{
GATA-4/-6 and HNF-1/-4 families of transcription factors control the transcriptional regulation of the murine Muc5ac mucin during stomach development and in epithelial cancer cells.
}

Nicolas Jonckheere, Audrey Vincent, Hélène Franquet-Ansart, Janneke Witte-Bouma, Anita Korteland-van Male, Emmanuelle Leteurtre, Ingrid B.

Renes, Isabelle van Seuningen

\section{To cite this version:}

Nicolas Jonckheere, Audrey Vincent, Hélène Franquet-Ansart, Janneke Witte-Bouma, Anita Korteland-van Male, et al.. GATA-4/-6 and HNF-1/-4 families of transcription factors control the transcriptional regulation of the murine Muc5ac mucin during stomach development and in epithelial cancer cells.: Regulation of Muc5ac by GATA- 6 and HNF- $4 \alpha$. BBA - Biochimica et Biophysica Acta, 2012, 1819 (8), pp.869-76. 10.1016/j.bbagrm.2012.04.003 . inserm-00807845

\section{HAL Id: inserm-00807845 https://www.hal.inserm.fr/inserm-00807845}

Submitted on 4 Apr 2013

HAL is a multi-disciplinary open access archive for the deposit and dissemination of scientific research documents, whether they are published or not. The documents may come from teaching and research institutions in France or abroad, or from public or private research centers.
L'archive ouverte pluridisciplinaire HAL, est destinée au dépôt et à la diffusion de documents scientifiques de niveau recherche, publiés ou non, émanant des établissements d'enseignement et de recherche français ou étrangers, des laboratoires publics ou privés. 


\section{Accepted Manuscript}

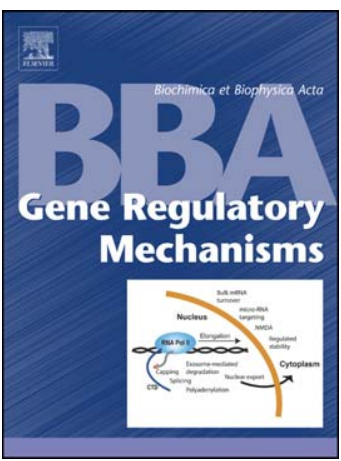

GATA-4/-6 and HNF-1/-4 families of transcription factors control the transcriptional regulation of the murine Muc5ac mucin during stomach development and in epithelial cancer cells

Nicolas Jonckheere, Audrey Vincent, Hélène Franquet-Ansart, Janneke Witte-Bouma, Anita Korteland-van Male, Emmanuelle Leteurtre, Ingrid B. Renes, Isabelle Van Seuningen

PII:

S1874-9399(12)00094-6

DOI: doi: 10.1016/j.bbagrm.2012.04.003

Reference: BBAGRM 482

To appear in: $\quad$ BBA - Gene Regulatory Mechanisms

Received date: 17 January 2012

Revised date: $\quad 13$ April 2012

Accepted date: $\quad 17$ April 2012

Please cite this article as: Nicolas Jonckheere, Audrey Vincent, Hélène Franquet-Ansart, Janneke Witte-Bouma, Anita Korteland-van Male, Emmanuelle Leteurtre, Ingrid B. Renes, Isabelle Van Seuningen, GATA-4/-6 and HNF-1/-4 families of transcription factors control the transcriptional regulation of the murine Muc5ac mucin during stomach development and in epithelial cancer cells, BBA - Gene Regulatory Mechanisms (2012), doi: 10.1016/j.bbagrm.2012.04.003

This is a PDF file of an unedited manuscript that has been accepted for publication. As a service to our customers we are providing this early version of the manuscript. The manuscript will undergo copyediting, typesetting, and review of the resulting proof before it is published in its final form. Please note that during the production process errors may be discovered which could affect the content, and all legal disclaimers that apply to the journal pertain. 


\section{GATA-4/-6 and HNF-1/-4 families of transcription factors control the transcriptional regulation of the murine Muc5ac mucin during stomach development and in epithelial cancer cells}

Nicolas Jonckheere ${ }^{1,2,3}$, Audrey Vincent ${ }^{1,2,3}$, Hélène Franquet-Ansart ${ }^{1,2,}{ }^{4}$, Janneke WitteBouma $^{5}$, Anita Korteland-van Male ${ }^{5}$, Emmanuelle Leteurtre ${ }^{1,2,4}$, Ingrid B. Renes ${ }^{5}$, and Isabelle Van Seuningen ${ }^{1,2,3}$

${ }^{1}$ Inserm, UMR837, Jean Pierre Aubert Research Center, Team \#5 "Mucins, epithelial differentiation and carcinogenesis”, rue Polonovski, 59045 Lille Cedex, France

${ }^{2}$ Université Lille Nord de France, 1 Place de Verdun, 59045 Lille cedex, France

${ }^{3}$ Centre Hospitalier Régional et Universitaire de Lille, Place de Verdun, 59037 LILLE cedex, France

${ }^{4}$ Centre de Biologie-Pathologie, Centre Hospitalier Régional et Universitaire de Lille, 2 avenue Oscar Lambret, 59037 Lille Cedex, France

${ }^{5}$ Erasmus Medical Center-Sophia, Laboratory of Pediatrics, Division of Neonatology, Dr. Molewaterplein 50, 3015 GE Rotterdam, the Netherlands.

Running title : Regulation of Muc5ac by GATA- 6 and HNF- $4 \alpha$

Keywords : Muc5ac, mucin, stomach, transcription, development, HNF, GATA.

To whom correspondence should be sent:

Nicolas Jonckheere, Ph.D. Inserm UMR837, Rue Polonovski, 59045 Lille cedex, France Phone : 33.320.29.88.50,FAX : 33.320.53.85.62, E-mail : nicolas.jonckheere@ inserm.fr 


\section{Abbreviations}

bp basepair

ED Embryonic Day

EMSA Electrophoretic Mobility Shift Assay

HNF Hepatocyte Nuclear Factor

$\mathrm{kb} \quad$ kilobase

PCR Polymerase Chain Reaction

PND Post Natal Day

RT Reverse Transcriptase

TF Transcription Factor 


\begin{abstract}
During human embryonic and fetal development of the gastrointestinal tract, the gene encoding the MUC5AC mucin has a spatio-temporal pattern of expression restricted to the stomach. In order to better understand the molecular mechanisms responsible for this restricted pattern of expression, we have studied Muc5ac expression in the developing stomach of the mouse and correlated it to that of transcription factors known to be involved in cell differentiation programs during development. Our results indicate that GATA-6 and HNF- $4 \alpha$ expression increased concomitantly with the induction of Muc5ac expression in embryonic stomach. We then studied $M u c 5 a c$ transcriptional regulation by these transcription factors and showed that they all transactivate Muc5ac promoter. We also identified several active GATA-4/-5/-6 and HNF-1/-4 cis-elements using gel shift assays, chromatin immunoprecipitation and site-directed mutagenesis. Among all Muc5ac regulators, only GATA-6 and HNF-4a expression was concomitant to that of Muc5ac in the developing stomach. This is thus in favour of an important role for these two transcription factors as regulators of expression of the Muc5ac mucin during stomach development and in epithelial cancer cells.
\end{abstract}




\section{Introduction}

Mucins are large $O$-glycoproteins expressed either at the cell surface as transmembrane proteins or as secreted oligomeric molecules to form a protective mucous gel [1-3]. In the stomach, MUC5AC is one of the main secreted mucins where it plays a cytoprotective role against acid and pepsin in the gastric juice, against deleterious effects of exogenous agents (pathogens, drugs) and against mechanical damage [2, 4]. In humans, MUC5AC is encoded by a gene located on the p15 arm of chromosome 11 within a cluster of four mucin genes along with $M U C 2, M U C 5 B$ and MUC6 [5]. In the mouse, the organization of the cluster and the structure of the genes are conserved and the mucin gene cluster is located in the syntenic region (murine chromosome 7) of the human chromosome 11 [6].

During human embryonic and fetal development of the gastrointestinal tract, $M U C 5 A C$ has a spatially restricted pattern of expression, which suggests that this mucin may play a role in gastrointestinal cell differentiation and proliferation [7-9]. MUC5AC is expressed as early as 8 weeks of gestation in embryonic stomach [9]. In developing stomach it is first visible in the region destined to become the antrum and later it becomes visible in the fundus. In the normal adult, MUC5AC is expressed in the mucin producing gastric pit cells of the stomach $[1,4]$. In the mouse, Muc5ac pattern of expression during development remains to be determined. Moreover, the molecular mechanisms that govern mouse Muc5ac expression are also unknown and most likely imply tight regulation by transcription factors (TF) involved in gastrointestinal differentiation $[7,8,10]$.

The molecular mechanisms controlling cell differentiation in the gastro-intestinal tract are mediated by several TF and especially those belonging to the hepatocyte nuclear factor (HNF), GATA and Caudal-related (Cdx) families [11-16]. In the stomach, only HNF and GATA TF are expressed. The GATA family consists in six members, GATA-1 to -6 , that bind to the 5'-(A/T)GATA(A/G)-3' response element via their zinc finger domains. GATA-4, 
-5 , and -6 are found mainly in heart and endoderm-derived tissues, including liver, lung, pancreas, stomach, and intestine [11]. Hepatocyte nuclear factors belong to a heterogeneous family of TF involved in a wide variety of biological pathways. They are involved in visceral endoderm differentiation and found in kidney, pancreas, stomach, small intestine, and colon [17]. HNF- $1 \alpha$ and HNF-1 $\beta$ are homeodomain proteins that bind the consensus sequence 5'GTTAATGATTAAC-3'. FOXA1 (HNF-3 $\alpha)$ and FOXA2 (HNF-3 $\beta$ ) belong to the forkhead/winged helix DNA binding domain family. They bind the consensus sequence 5'GATTATTGACTT-3' [18] and are expressed in embryonic endoderm and in the adult intestine [19]. HNF-4 $\alpha$ and HNF-4 $\gamma$ are members of the steroid hormone receptor family. They are zinc finger TF and bind the consensus sequence 5'-TGGACTTAG-3'.

Despite an increasing amount of data regarding the expression pattern of mucins in normal and pathological epithelia of human $[1,4,10]$ and rodents $[20,21]$, the precise biological role of mucins as well as the mechanisms that govern their specific pattern of expression during embryonic development and adult differentiation in the gastrointestinal tract remain largely unknown. To this aim, we have previously cloned and characterized the 5'-flanking region of the mouse Muc5ac [22]. In this report, we have investigated the transcriptional regulation of the gastric Muc5ac mucin gene by gastric HNF and GATA TFs. We show that the expression of the murine Muc5ac mucin in developing stomach is correlated to that of HNF- $4 \alpha$ and GATA-6. We also show that GATA-4 and HNF- $1 \alpha /-1 \beta$ may be important regulators of Muc5ac transcription. 


\section{Experimental}

\subsection{Animals}

Adult specified pathogen free Balb/c mice, obtained from Harlan (Zoetermeer, The Netherlands), were sacrificed by cervical dislocation. Stomach from embryo (ED15.5, ED17.5 and ED18.5) and adult mice were removed and fixed in 4\% (w/v) paraformaldehyde in phosphate-buffered saline and subsequently processed for light microscopy as previously described [23]. The animal experiments were reviewed and performed with the approval of the Animal Studies Ethics Committee of the Erasmus MC (Rotterdam, the Netherlands).

\subsection{Histology - Immunohistochemistry}

Five $\mu$ m-thick sections of mouse stomach tissue were routinely stained with hematoxylin and eosin to study the morphology, or stained with Periodic Acid Schiff (PAS) reagent to stain for neutral mucins. Immunolocalization of mouse Muc5ac was carried out as previously described [22] using 45M1 monoclonal antibody (Novocastra). Anti-HNF-1 $\alpha$ (sc6547), FOXA2 (sc-6554), HNF-4 $\alpha$ (sc-6556), HNF-4 $\gamma$ (sc-6558), GATA-4 (sc-1237), GATA-6 (sc-7244) antibodies were from Santacruz Laboratories (TEBU-BIO).

\subsection{Cell culture}

The murine rectal cancer cell line CMT-93 was cultured in Dulbecco's Modified Essential Medium containing 10\% (v/v) fetal bovine serum, $4 \mathrm{mM}$ L-glutamine, penicillin (100 U/ml), and streptomycin $(100 \mu \mathrm{g} / \mathrm{ml})$ at $37^{\circ} \mathrm{C}$ in a humidified $5 \% \mathrm{CO}_{2}$ water-jacketed incubator as previously described [22]. 


\subsection{RT-PCR}

Total RNA from CMT-93 cells were prepared using the NucleoSpin® RNA II kit (Macherey Nagel) following the manufacturer's protocol. cDNAs were prepared as previously described [24]. Total RNA $\left(1.5 \mu \mathrm{g}\right.$ ) was used to prepare first strand cDNA (Advantage ${ }^{\mathrm{TM}}$ RTfor-PCR kit, Clontech). PCR was performed on $2 \mu$ of cDNA using specific pairs of primers as previously described [24]. The annealing temperature was $58^{\circ} \mathrm{C}$. Muc5ac forward primer: 5'-GAGGGCCCAGTGAGCATCTCC-3', Muc5ac reverse primer: 5'TGGGACAGCAGCAGTATTCAGT-3' (accession number AJ010792). $\beta$-actin was used as an internal control: mouse $\beta$-actin forward primer: 5'-GTGGGCCGCTCTAGGCACCA-3', mouse $\beta$-actin reverse primer: 5'-TGGCCTTAGGGTGCAGGGGG-3' (accession number M12481). Muc5ac and $\beta$-actin PCR product sizes are 361 and $582 \mathrm{bp}$, respectively. $100 \mathrm{bp}$ DNA ladder was purchased from Amersham Bioscience. To study the effect of TF overexpression on endogenous Muc5ac mRNA level, cells $\left(0.5 \times 10^{6}\right)$ were transfected as before [25] with $2 \mu \mathrm{g}$ of the expression vectors of interest and cultured for $48 \mathrm{~h}$ before being lysed and processed for total RNA preparation and RT-PCR analysis. The Muc5ac/ $\beta$-actin ratio was calculated by densitometric analysis of the DNA bands on the agarose gel by using the GelAnalyst-GelSmart software (Clara Vision, Paris, France). These experiments were performed in triplicate in three independent series.

\subsection{Site-directed mutagenesis}

QuickChange site-directed mutagenesis kit (Stratagene) was used to generate sitespecific mutations in GATA and HNF binding sites in Muc5ac promoter as described previously in Mesquita et al. [24]. Oligonucleotides containing the desired mutations were 
designed according to the manufacturer's instructions and their sequences are depicted in Table I.

\subsection{Transfections}

Transfections and co-transfections experiments were performed using Effectene ${ }^{\circledR}$ reagent (Qiagen) as previously described [26]. The Muc5ac-pGL3 deletion mutants covering $1.2 \mathrm{~kb}$ upstream of the first ATG were previously described [22]. Total cell extracts were prepared after a $48 \mathrm{~h}$ incubation at $37^{\circ} \mathrm{C}$ using $1 \mathrm{X}$ Reagent Lysis Buffer (Promega) as described in the manufacturer's instruction manual. Luciferase activity $(20 \mu \mathrm{l})$ was measured on a TD 20/20 luminometer (Turner Design). Total protein content in the extract (4 $\mu 1)$ was measured using the bicinchoninic acid method in 96-well plates as described in the manufacturer's instruction manual (Pierce, Bezons, France). In co-transfection experiments, 1 $\mu \mathrm{g}$ of $M u c 5 a c-p G L 3$ constructs were transfected in the presence of $0.25 \mu \mathrm{g}$ of the expression vector encoding the TF of interest. Relative luciferase activity was expressed as fold activation of luciferase activity in the sample with the expression vector compared to that with the empty vector (Ref.). Each combination was assayed in triplicate in three separate experiments.

\subsection{Nuclear extract preparation}

Nuclear extracts from the different cells were prepared as described by Van Seuningen et al. [27], and kept at $-80^{\circ} \mathrm{C}$ until use. Protein content ( $2 \mu \mathrm{l}$ of cell extracts) was measured using the bicinchoninic acid as described above. 


\subsection{Oligonucleotides and DNA probes}

The sequences of the oligonucleotides (wild type and mutated) used for gel-shift assays are indicated in Table I. They were synthesized by MWG-Biotech (Germany). Equimolar amounts of single-stranded oligonucleotides were annealed and radiolabelled using T4 polynucleotide kinase (Promega) and $\left[\gamma^{32} \mathrm{P}\right]$-dATP. Radiolabelled probes were purified by chromatography on a Bio-Gel P-6 column (BIORAD, Ivry-sur-Seine, France).

\subsection{Electrophoretic mobility shift assays (EMSA)}

Nuclear proteins $(8 \mu \mathrm{g})$ were pre-incubated for $20 \mathrm{~min}$ on ice in $20 \mu \mathrm{l}$ binding buffer with $1 \mu \mathrm{g}$ of poly dI-dC (Sigma) and $1 \mu \mathrm{g}$ sonicated salmon sperm DNA. Radiolabelled DNA probe was added (60,000 c.p.m.) and the reaction was left for another 20 min on ice. For super-shift analyses, $1 \mu \mathrm{l}$ of the antibody of interest (anti-GATA-4, anti-GATA-6, anti-HNF$1 \alpha$, anti-HNF-1 $\beta$, anti-FOXA1, anti-FOXA2, anti-HNF4- $\alpha$, anti-HNF- $\gamma$, Santa-Cruz laboratories, TEBU-BIO, France) was added to the proteins and left for $30 \mathrm{~min}$ at RT before adding the radiolabelled probe. Cold competition were performed by preincubating nuclear proteins with $100 \mathrm{X}$ excess of unlabelled oligonucleotides before adding radioactive probe. Mutated oligonucleotides were also used under the same conditions to demonstrate the specificity of the binding. Reactions were stopped by adding $2 \mu \mathrm{l}$ of loading buffer. Samples were loaded onto a $4 \%$ non-denaturing polyacrylamide gel and electrophoresis conditions were as described in [28]. Gels were vacuum-dried and autoradiographed overnight at $-80^{\circ} \mathrm{C}$. EMSA were performed independently at least three times.

\subsection{Chromatin immunoprecipitation assays (ChIP)}


The Chromatin Immuno Precipitation (ChIP) assay was carried out as previously described [29] using 4 mg of anti-GATA-4, anti-GATA-5 (R\&D) and anti-GATA-6 (N18 from Santa Cruz Biotechnology), anti-HNF1 $\alpha$, anti-HNF1 $\beta$, anti-HNF4 $\alpha$ and HNF4 $\gamma$ (Santa Cruz Biotechnology) antibodies or normal rabbit IgGs (Upstate, Millipore, St Quentin en Yvelines, France). Immuno-precipitation was performed using Dynabeads ${ }^{\circledR}$ magnetic beads A and G (Invitrogen) with Dynabeads ${ }^{\circledR}$ rack (Invitrogen) following the manufacturer's protocol. The sequences of PCR primers covering DNA regions of interest are indicated in table I. PCR was carried out in a $30 \mu \mathrm{l}$ volume containing $50 \mathrm{ng}$ of DNA, 5U of AmpliTaq Gold (Applied Biosystems, Courtaboeuf, France), $0.5 \mathrm{mM}$ of each primer, $2.5 \mathrm{mM} \mathrm{MgCl}_{2}$ and $5 \%(\mathrm{v} / \mathrm{v})$ dimethylsulphoxide using the following protocol: $3 \mathrm{~min}$ at $95^{\circ} \mathrm{C}$ followed by $\left(\left(95^{\circ} \mathrm{C}\right) 15 \mathrm{~s}\right.$, $\left.\left(55^{\circ} \mathrm{C}\right) 15 \mathrm{~s},\left(72^{\circ} \mathrm{C}\right) 15 \mathrm{~s}\right)$ for 34 cycles, and $72^{\circ} \mathrm{C}$ for $5 \mathrm{~min}$. The PCR products were analysed on a $1.2 \%(\mathrm{w} / \mathrm{v})$ agarose gel run in $1 \mathrm{X}$ tris borate-EDTA containing ethidium bromide.

\subsection{Statistical analysis}

Statistical analyses were performed using Graphpad Prism 4.0 software (Graphpad softwares Inc., La Jolla, USA). Data are presented as mean \pm SEM. Differences in the mean of two samples were analysed by the student's t test or one way ANOVA test with selected comparison using tukey post-hoc test with differences less than 0.05 considered significant and were indicated with an $* * *$ indicates $\mathrm{p}<0.01$. 


\section{Results}

\subsection{Expression of Muc5ac and transcription factors during development of the mouse}

\section{stomach}

Expression of the Muc5ac mucin during developing stomach of the mouse was studied by immunohistochemistry (IHC) at embryonic days (ED) 15.5, 17.5, 18.5, post-natal day 1.5 (PND1.5) and in adult mice. As shown in figure 1, Muc5ac was expressed in embryonic stomach as of ED18.5. The staining was localized in the surface epithelial cells. Muc5ac staining was conserved at PND1.5 (supplemental figure 1) and in adult mouse (Figure 1). A similar pattern was observed with PAS staining. Expression of TF known to be involved in epithelial cell differentiation during gastrointestinal development was then studied in order to correlate their expression with that of Muc5ac. GATA-6 and HNF- $4 \alpha$ expression in the stomach was only observed as of ED17.5, shortly before the outgrowth of the hindstomach into a glandular stomach (not shown). Their expression remained weak until ED18.5 but increased substantially after birth (Figure 1). GATA-4, HNF-1 $\alpha$, HNF-4 $\gamma$ and FOXA2 are expressed as early as ED15.5 in the pseudostratified epithelium of the hindstomach and throughout development, after birth and in adult mice (not shown). As of ED17.5 all of the TF studied were expressed in epithelial cells from the bottom to the top of the glands. Among all the TF studied, only GATA- 6 and HNF- $4 \alpha$ were expressed right before the induction of Muc5ac expression. IHC performed on serial sections of PND1.5 mouse stomach showed that Muc5ac, GATA-6 and HNF-4 $\alpha$ were expressed in the surface epithelial cells of the stomach (supplemental figure 1). 


\subsection{Muc5ac gene is transcriptionally regulated by HNF-1/-4 and GATA-4/-5/-6 transcription factors}

Having shown that the Muc5ac mucin is co-expressed with HNF and GATA TF during stomach development we undertook to study their effect on Muc5ac transcription. To this end, co-transfection experiments were performed with two deletion fragments of $M u c 5 a c$ promoter $(-3070 /+3$ and $-1021 /+3)$ in the presence of expression vectors encoding the $\mathrm{TF}$ of interest. The longest fragment contains two putative GATA (T127 and T191) and two putative HNF-4 (T122 and T126) binding sites, respectively (Figure 2A). The Muc5ac promoter does not contain any HNF-1 5'-TAGTTAC-3' consensus binding site. Promoter activity and mRNA expression were evaluated by measurement of luciferase activity and by RT-PCR, respectively.

Co-transfection studies in CMT-93 cells (Figure 2A), indicated that among the three GATA TF, GATA-5 had the strongest effect on $M u c 5 a c$ promoter activity ( 8 fold activation on the $-3070 /+3$ fragment, black bars), whereas GATA-4 and GATA- 6 were less active (4 fold activation). The transactivation profile was the same on the shortest fragment $(-1021 /+3$, gray bars) with a slightly weaker activation (2- and 6- fold, respectively).

Regulation of the Muc5ac promoter by HNF factors indicated that HNF-1 $\beta$ is the most potent transactivator (10 fold on fragment $-3070 /+3)$. The transactivating effect decreased substantially when the shortest fragment was used indicating that distal HNF binding sites may be important in mediating HNF-1 $\beta$ effects. HNF- $1 \alpha$, HNF- $4 \alpha$ and HNF- $4 \gamma$ also transactivated the Muc5ac promoter but to a lesser extent (2 fold activation). Members of the FOXA family (FOXA1, FOXA2, FOXA3) did not induce Muc5ac promoter activity.

At the mRNA level, we observed an increase of Muc5ac expression with GATA-4 (1.8 fold, $\mathrm{p}=0.0015, * *)$ GATA-5 (4.7 fold, $\mathrm{p}=0.0064, * *)$ and GATA-6 (2.8 fold, $\mathrm{p}=0.0291, *)$ once we had overexpressed these TF in CMT-93 cells. Overexpression of HNF-1 $\alpha$, HNF-1 $\beta$, 
HNF- $4 \alpha$ and HNF- $4 \gamma$ also induced an increase of Muc5ac mRNA level in CMT-93 cells (2.6, 3.8, 1.3 and 1.5 fold, respectively, $\mathrm{p}=0.0324 *, \mathrm{p}=0.0449 *, \mathrm{p}=0.46$ and $\mathrm{p}=0.023 *$, respectively), while no effect was observed with FOXA1, FOXA2 and FOXA3 (Figure 2B).

Since these TF are known to act in synergy, this possibility was investigated on Muc5ac promoter activity by transient co-transfection experiments. The results indicate additive effects for GATA-6 and HNF-1 $\beta$ and GATA-6 and HNF-4 $\alpha$ (Figure 2C).

In conclusion, we have identified GATA-4/-5/-6 and HNF- $1 \alpha /-1 \beta$ as strong transactivators of Muc5ac promoter activity and mRNA expression and HNF- $4 \alpha /-4 \gamma$ as weaker transactivators.

\subsection{Muc5ac promoter contains GATA-4/-5//-6 and HNF-1/-4 cis-elements}

The sequence upstream of the TATA box is characterized by the presence of putative binding sites for members of the HNF (T122 and T126) and GATA (T127 and T191) TF families (Figure 2A). In order to identify which factor binds, if any, to these sites, EMSA and ChIP assays were carried out.

Using EMSA (Figure 3A), a GATA binding site was identified at -774/-771 as two shifted bands appeared when the double-stranded radiolabelled probe T127 was incubated with nuclear proteins from CMT-93 cells (lane 2). The specificity of the binding was confirmed by cold competition that abolished formation of the two complexes (lane 3). The binding of GATA-4 and GATA- 6 to this site was confirmed by preincubation of the extract with anti-GATA-4 and anti-GATA-6 antibodies that led to the disappearance of the upper shifted band for GATA-4 (lane 4) and disappearance of the lower shifted band and formation of a supershift for GATA-6 (ssGATA-6, lane 5). Incubation with the T191 (-2521/-2518 distal GATA site) probe did not result in any shifted band (not shown). 
Incubation with the T126 and T122 radiolabelled probes that contain the proximal (-634/630) and distal (-2614/-2610) HNF-4 binding sites produced retarded bands (lanes 7 and 14). The binding was specific since it disappeared when cold competition was performed with 100x excess of wild-type T126 or T122 probes (lanes 8 and 15) and was maintained when a mutated version of the probes was used (lanes 9 and 16). Incubation with anti-HNF-1 $\alpha$ (lanes 10 and 17), anti-HNF-1 $\beta$ (lanes 11 and 18), anti-FOXA1 (lanes 12 and 19), anti-FOXA2 (lane 20) did not produce supershifts but only slightly reduced the intensity of the shifted bands (22, 29, 31 and 31\% decrease for T122 binding site and 49 and 46\% for T126 binding site, respectively). Incubation with antibodies for HNF-4 $\alpha$ (lanes 13 and 21) and HNF-4 $\gamma$ (lane 22) led to supershifted bands.

In order to confirm these interactions in cellulo, ChIP assays were carried out on the 1019/-723 region of Muc5ac promoter containing the T127 (-774/-771) GATA-4/-6 binding site and on the -2904/-2608 and -769/-544 regions containing the T122 and T126 HNF-4 binding sites, respectively (Figure 3B). The results indicate that GATA-6 and to a lesser extent GATA-4 and GATA-5 bind to the $-1019 /-723$ Muc5ac promoter region (Figure 3B). HNF- $1 \alpha$, HNF- $1 \beta$, HNF- $4 \alpha$ and HNF- $4 \gamma$ TF were found to strongly bind to the $-769 /-544$ promoter region (T126) (Figure 3C). They also bound with less intensity to the -2904/-2608 (T122) region. Specificity of the bindings in all ChIPs was confirmed by absence of PCR amplification in the presence of IgGs.

In conclusion of these binding assays, we have identified one GATA-4/-5/-6 cis-element at -774/-771 (T127) and two HNF-4 $\alpha /-4 \gamma$ cis-elements at -634/-630 (T126) and -2614/-2610 (T122) within the Muc5ac promoter. Moreover, -769/-544 and -2904/-2608 promoter regions are also able to bind HNF- $1 \alpha /-1 \beta$ on cis-elements that remain to be identified. 
We have also investigated whether HNF-1 may modulate the levels of HNF- $4 \alpha /-4 \beta$ or GATA-6. We thus performed RT-PCR on RNA extracts from CMT-93 cells transfected with expression vectors encoding either HNF- $1 \alpha$ or HNF- $1 \beta$. Although HNF- $1 \alpha /-1 \beta$ expression was increased as expected, HNF- $4 \alpha$, HNF- $4 \gamma$ or GATA- 6 mRNA levels were not modified (Supplemental figure 2). These results are thus not in favour of a regulatory mechanism of HNF $4 \alpha / 4 \gamma$ and GATA-6 by HNF- $1 \alpha /-1 \beta$.

\subsection{HNF-1/-4 and GATA-4/-6 cis-elements mediate Muc5ac transcriptional activity}

In order to confirm the importance of the two GATA and HNF cis-elements in the transcriptional regulation of $M u c 5 a c$ promoter, site-directed mutagenesis of these sites was performed. The luciferase diagram indicates that mutation of the proximal HNF-1/-4 ciselement at -634/-630 (T126) led to a total loss of the transactivating effect mediated by HNF$1 \alpha$ and HNF- $1 \beta$ that was statistically significant $(\mathrm{p}<0.05$ ) (grey bars) (Figure 4A). Loss of transactivation by HNF- $4 \alpha$ and HNF- $4 \gamma$ was also observed but remained statistically non significant. A total loss in Muc5ac promoter transactivation, significant for HNF- $1 \alpha$, HNF- $1 \beta$ and HNF-4 $\alpha$ was also observed when the distal cis-element at -2614/-2610 (T122) was mutated (black bars).

Mutation of the GATA T127 (-774/-771) cis-element in the $-1021 /+3$ construct induced a statistically significant $(\mathrm{p}<0.05)$ decrease of $M u c 5 a c$ promoter activity in the presence of GATA-4 and GATA-6 (grey bars) when compared to the activity with the non-mutated construct (white bar) (Figure 4B). Transactivation by GATA-5 was not affected. As expected mutagenesis of the distal GATA element located at -2521/-2518 (T191), where no binding was observed did not alter transactivation of the $-3070 /+3$ construct (not shown). 
Altogether, these results indicate that -634/-630 (T126) and -2614/-2610 (T122) HNF ciselements are necessary to convey Muc5ac promoter activity by HNF- $1 \alpha /-1 \beta$ and HNF$4 \alpha /-4 \gamma$. Similarly, the $-777 /-771$ GATA cis-element (T127) is necessary to convey Muc5ac promoter activation by GATA-4 and GATA- 6 . 


\section{Discussion}

The Human MUC5AC mucin is expressed very early during human embryonic development before any mucous cytodifferentiation has started in the stomach [9]. In the present work, we show that the murine Muc5ac mucin is expressed at ED18.5 in the mouse embryonic stomach and maintained during adulthood. These results have led us to hypothesize that mucin genes expressed early during development may play important roles in establishment of cell lineages derived from endoderm and cells committed to become mucus-secreting $[1,7,10]$. Genes specifically regulated during those events are often targets of $\mathrm{TF}$ expressed during the same key events of cytodifferentiation. TF involved in gastrointestinal differentiation have been identified [11, 14, 15, 30-32] and belong notably to the GATA and HNF families. These factors also have a spatio-temporal pattern of expression during development. They regulate several enterocyte-specific genes such as sucrase isomaltase [33, 34], intestinal fatty acid binding protein [35], lactase-phlorizin hydrolase [33, 36] but also human and mouse $M u c 2, M u c 5 b$ and $M U C 4$ mucin genes [25, 29, 37, 38]. In this paper, we show for the first time that the murine $M u c 5 a c$ mucin gene is also regulated at the transcriptional level by GATA-4/-5/-6, HNF- $1 \alpha /-1 \beta$, HNF- $4 \alpha$ and HNF-4 $\gamma$ transcription factors.

In relation with the role of GATA-4/-5/-6 TF in gastrointestinal development $[11,31$, 32], we studied their effect on Muc5ac regulation. We found that the three TF up-regulate Muc5ac. These factors are all expressed in the visceral endoderm, developing gut and are found in cells lining the lumen of the primitive stomach at E11.5-12.5 of the mouse [39]. It is also striking that GATA-4/-5/-6 TF and $M u c 5 a c$ follow the same pattern of expression during development of the gut. They are transcribed in the small intestine only during embryogenesis but are not maintained in the adult whereas in stomach, their expression is maintained in the 
adult in specialized surface epithelial cells. GATA-5 also regulates genes important in the earlier commitment step of specialized cell types, since it was found in predifferentiated crypt cells of the gut epithelium [40], a cell type in which $M U C 5 A C$ is also present at that stage of development [8]. However, from our site-directed mutagenesis data Muc5ac regulation by GATA-5 is most likely indirect. Altogether, these data and ours reveal a new mechanism of regulation of $M U C 5 A C$ by GATA factors during stomach development and early commitment of future specialized mucus-secreting cells.

HNF factors belong to a structurally heterogeneous family of TF and are known to be involved in the development and differentiation of the gastrointestinal tract $[12,14,15]$. In order to delineate which HNF transcription factors are important in Muc5ac regulation we used a large panel of expression vectors encoding HNF- $1 \alpha / 1 \beta$, FOXA1/A2/A3 and HNF- $4 \alpha /$ $4 \gamma$. Our data show that HNF-1 $\alpha$ and HNF-1 $\beta$ are strong activators of Muc5ac transcription both at the promoter and RNA levels. These TF are known to regulate several intestinespecific genes $[33,34,36]$, that are markers of enterocytes. We show now for the first time similar mechanisms of regulation at the transcriptional level for $M u c 5 a c$, a specific marker of gastric mucus-secreting cells.

In the present work, we also show that the Muc5ac mucin is expressed concomitantly with GATA-6 and HNF-4 $\alpha$ TF during stomach development and that Muc5ac gene is transcriptionally regulated by these two TF. This suggests that the spatio-temporal pattern of expression of Muc5ac, which participates in mucus-secreting lineage establishment and epithelial differentiation of tissues derived from primitive gut, especially in embryonic stomach is probably under the control of these two TF. HNF-4 and GATA-6 are also known to control the expression of genes specifically expressed in other territories of the digestive tract such as the intestine. However, Muc5ac is not expressed in the normal gut suggesting that other regulatory mechanisms are involved. In the laboratory, recent works in humans 
have indeed confirmed this hypothesis as transient expression of MUC5AC in colon carcinoma was found to be correlated with demethylation of the $\mathrm{CpG}$ island found in its 5'flanking region [41]. Since the same pattern of expression is observed for Muc5ac in the mouse intestine, one may hypothesize that epigenetic regulation of Muc5ac also occurs.

The relatively modest transactivating effect of HNF- $4 \alpha$ is not surprising as it is wellknown that this TF is a weak transactivator [42] which often acts in synergy or in combination with other TF. We previously showed that GATA and HNF TF act synergistically to regulate MUC4 gene expression in epithelial cells [38]. One can envision a similar mechanism involving HNF-4 $\alpha$ and GATA-6 regarding Muc5ac regulation similarly to what was shown for ATP-Binding Cassette Sterol Transporters $A B C G 5$ and $A B C G 8$ for which HNF-4 $\alpha$ contributes to maintaining the basal transcriptional activities and acts synergistically with GATA TF to activate transcription [42]. Co-transfection experiments carried out in the presence of the two TF showed additive effects for GATA- 6 and HNF- $1 \beta$ or GATA- 6 and HNF-4 $\alpha$.

In conclusion, we have shown that $M u c 5 a c$ is regulated at the transcriptional level by TF involved in gastrointestinal development and goblet cell differentiation (GATA-4/-5/-6, HNF- $1 \alpha /-1 \beta$, HNF- $4 \alpha /-4 \gamma$ ). These results open new avenues of research in animal models that will aim at demonstrating the importance of $M u c 5 a c$ in maintaining gastrointestinal homeostasis and correlate Muc5ac expression during development of the epithelium with mucus surface cell differentiation [21, 43]. In the long run, a better understanding of the role of mucins in health and disease may allow the development of novel therapeutic targets and preventive strategies. 
5. Acknowledgements: We are indebted to Monique Melis for her excellent technical help. We thank Dr. J. K. Divine (Washington University, St-Louis, MO, USA) for the kind gift of GATA-5, GATA-6, HNF-1 $\alpha$, HNF-1 $\beta$, FOXA1, FOXA2, FOXA3, HNF-4 $\alpha$, HNF-4 $\gamma$ expression vectors, Dr. S. Cereghini (UMR7622 CNRS, Université Pierre et Marie Curie, Paris, France) for the kind gift of pMT2-GATA-4 expression vector. This work was supported by a grant from l'Association François Aupetit (IVS). N. Jonckheere is the recipient of a Ligue Nationale contre le Cancer (LNCC) postdoctoral fellowship. Isabelle Van Seuningen is the recipient of a "Contrat Hospitalier de Recherche Translationnelle"/CHRT 2010, AVIESAN. 


\section{References}

[1] I. Van Seuningen, E. Leteurtre, Mucin expression and regulation in the gastro-intestinal tract. Actors of carcinogenesis?, in: I. Van Seuningen (Ed.) The Epithelial Mucins: Structure/Function. Roles in Cancer and Inflammatory Diseases, Research Signpost, Kerala, India, 2008, pp. 183-210.

[2] M.A. McGuckin, S.K. Linden, P. Sutton, T.H. Florin, Mucin dynamics and enteric pathogens, Nat Rev Microbiol, 9 265-278.

[3] J. Dekker, J.W. Rossen, H.A. Buller, A.W. Einerhand, The MUC family: an obituary, Trends Biochem Sci, 27 (2002) 126-131.

[4] A.P. Corfield, D. Carroll, N. Myerscough, C.S. Probert, Mucins in the gastrointestinal tract in health and disease, Front Biosci, 6 (2001) D1321-1357.

[5] P. Pigny, V. Guyonnet-Duperat, A.S. Hill, W.S. Pratt, S. Galiegue-Zouitina, M.C. d'Hooge, A. Laine, I. VanSeuningen, P. Degand, J.R. Gum, Y.S. Kim, D.M. Swallow, J.P. Aubert, N. Porchet, Human mucin genes assigned to 11p15.5: identification and organization of a cluster of genes, Genomics, 38 (1996) 340-352.

[6] J.L. Desseyn, A. Laine, Characterization of mouse muc6 and evidence of conservation of the gel-forming mucin gene cluster between human and mouse, Genomics, 81 (2003) 433-436.

[7] M.P. Buisine, N. Porchet, I. Van Seuningen, Mucin expression and regulation during development and cell differentiation, in: I. Van Seuningen (Ed.) The Epithelial Mucins: Structure/Function. Roles in Cancer and Inflammatory Diseases, Research Signpost, Kerala, India, 2008, pp. 75-94.

[8] M.P. Buisine, L. Devisme, T.C. Savidge, C. Gespach, B. Gosselin, N. Porchet, J.P. Aubert, Mucin gene expression in human embryonic and fetal intestine, Gut, 43 (1998) 519-524.

[9] M.P. Buisine, L. Devisme, V. Maunoury, E. Deschodt, B. Gosselin, M.C. Copin, J.P. Aubert, N. Porchet, Developmental mucin gene expression in the gastroduodenal tract and accessory digestive glands. I. Stomach. A relationship to gastric carcinoma, J Histochem Cytochem, 48 (2000) 1657-1666.

[10] I. Van Seuningen, P. Pigny, M. Perrais, N. Porchet, J.P. Aubert, Transcriptional regulation of the 11p15 mucin genes. Towards new biological tools in human therapy, in inflammatory diseases and cancer?, Front Biosci, 6 (2001) D1216-1234.

[11] J.D. Molkentin, The zinc finger-containing transcription factors GATA-4, -5, and -6. Ubiquitously expressed regulators of tissue-specific gene expression, J Biol Chem, 275 (2000) 38949-38952.

[12] R.K. Montgomery, A.E. Mulberg, R.J. Grand, Development of the human gastrointestinal tract: twenty years of progress, Gastroenterology, 116 (1999) 702-731.

[13] C.A. Richmond, D.T. Breault, Regulation of gene expression in the intestinal epithelium, Prog Mol Biol Transl Sci, 96 (2010) 207-229.

[14] P.G. Traber, D.G. Silberg, Intestine-specific gene transcription, Annu Rev Physiol, 58 (1996) 275-297.

[15] P. Traber, G.D. Wu, Gastrointestinal cancers: Biology, Diagnosis, and Therapy, Lippincott-Raven publishers, Philadelphia, 1995.

[16] S.A. Duncan, K. Manova, W.S. Chen, P. Hoodless, D.C. Weinstein, R.F. Bachvarova, J.E. Darnell, Jr., Expression of transcription factor HNF-4 in the extraembryonic endoderm, gut, and nephrogenic tissue of the developing mouse embryo: HNF-4 is a marker for primary endoderm in the implanting blastocyst, Proc Natl Acad Sci U S A, 91 (1994) 7598-7602.

[17] S. Cereghini, Liver-enriched transcription factors and hepatocyte differentiation, Faseb J, 10 (1996) 267 282.

[18] R. Hromas, R. Costa, The hepatocyte nuclear factor-3/forkhead transcription regulatory family in development, inflammation, and neoplasia, Crit Rev Oncol Hematol, 20 (1995) 129-140.

[19] K.H. Kaestner, H. Hiemisch, B. Luckow, G. Schutz, The HNF-3 gene family of transcription factors in mice: gene structure, cDNA sequence, and mRNA distribution, Genomics, 20 (1994) 377-385.

[20] V. Gouyer, F. Gottrand, J.L. Desseyn, The extraordinarily complex but highly structured organization of intestinal mucus-gel unveiled in multicolor images, PLoS One, 6 (2011) e18761.

[21] M.G. Roy, M. Rahmani, J.R. Hernandez, S.N. Alexander, C. Ehre, S.B. Ho, C.M. Evans, Mucin production during prenatal and postnatal murine lung development, Am J Respir Cell Mol Biol, 44 (2011) 755-760.

[22] N. Jonckheere, M. Van Der Sluis, A. Velghe, M.P. Buisine, M. Sutmuller, M.P. Ducourouble, P. Pigny, H.A. Buller, J.P. Aubert, A.W. Einerhand, I. Van Seuningen, Transcriptional activation of the murine Muc5ac mucin gene in epithelial cancer cells by TGF-beta/Smad4 signalling pathway is potentiated by Sp1, Biochem J, 377 (2004) 797-808. 
[23] I.B. Renes, J.A. Boshuizen, D.J. Van Nispen, N.P. Bulsing, H.A. Buller, J. Dekker, A.W. Einerhand, Alterations in Muc2 biosynthesis and secretion during dextran sulfate sodium-induced colitis, Am J Physiol Gastrointest Liver Physiol, 282 (2002) G382-389.

[24] P. Mesquita, N. Jonckheere, R. Almeida, M.P. Ducourouble, J. Serpa, E. Silva, P. Pigny, F.S. Silva, C. Reis, D. Silberg, I. Van Seuningen, L. David, Human MUC2 mucin gene is transcriptionally regulated by Cdx homeodomain proteins in gastrointestinal carcinoma cell lines, J Biol Chem, 278 (2003) 51549-51556.

[25] M. van der Sluis, M.H. Melis, N. Jonckheere, M.P. Ducourouble, H.A. Buller, I. Renes, A.W. Einerhand, I. Van Seuningen, The murine Muc2 mucin gene is transcriptionally regulated by the zinc-finger GATA-4 transcription factor in intestinal cells, Biochem Biophys Res Commun, 325 (2004) 952-960.

[26] M. Perrais, P. Pigny, M.P. Buisine, N. Porchet, J.P. Aubert, I. Van Seuningen-Lempire, Aberrant expression of human mucin gene MUC5B in gastric carcinoma and cancer cells. Identification and regulation of a distal promoter, J Biol Chem, 276 (2001) 15386-15396.

[27] I. Van Seuningen, J. Ostrowski, X.R. Bustelo, P.R. Sleath, K. Bomsztyk, The K protein domain that recruits the interleukin 1-responsive $\mathrm{K}$ protein kinase lies adjacent to a cluster of c-Src and Vav SH3-binding sites. Implications that K protein acts as a docking platform, J Biol Chem, 270 (1995) 26976-26985.

[28] I. Van Seuningen, M. Perrais, P. Pigny, N. Porchet, J.P. Aubert, Sequence of the 5'-flanking region and promoter activity of the human mucin gene MUC5B in different phenotypes of colon cancer cells, Biochem J, 348 Pt 3 (2000) 675-686.

[29] N. Jonckheere, A. Velghe, M.P. Ducourouble, M.C. Copin, I.B. Renes, I. Van Seuningen, The mouse Muc5b mucin gene is transcriptionally regulated by thyroid transcription factor-1 (TTF-1) and GATA-6 transcription factors, Febs J, 278 (2011) 282-294.

[30] R.K. Patient, J.D. McGhee, The GATA family (vertebrates and invertebrates), Curr Opin Genet Dev, 12 (2002) 416-422.

[31] C.M. Jacobsen, N. Narita, M. Bielinska, A.J. Syder, J.I. Gordon, D.B. Wilson, Genetic mosaic analysis reveals that GATA-4 is required for proper differentiation of mouse gastric epithelium, Dev Biol, 241 (2002) 3446.

[32] P. Bossard, K.S. Zaret, GATA transcription factors as potentiators of gut endoderm differentiation, Development, 125 (1998) 4909-4917.

[33] S.D. Krasinski, H.M. Van Wering, M.R. Tannemaat, R.J. Grand, Differential activation of intestinal gene promoters: functional interactions between GATA-5 and HNF-1 alpha, Am J Physiol Gastrointest Liver Physiol, 281 (2001) G69-84.

[34] F. Boudreau, E.H. Rings, H.M. van Wering, R.K. Kim, G.P. Swain, S.D. Krasinski, J. Moffett, R.J. Grand, E.R. Suh, P.G. Traber, Hepatocyte nuclear factor-1 alpha, GATA-4, and caudal related homeodomain protein $\mathrm{Cdx} 2$ interact functionally to modulate intestinal gene transcription. Implication for the developmental regulation of the sucrase-isomaltase gene, J Biol Chem, 277 (2002) 31909-31917.

[35] J.N. Rottman, J.I. Gordon, Comparison of the patterns of expression of rat intestinal fatty acid binding protein/human growth hormone fusion genes in cultured intestinal epithelial cell lines and in the gut epithelium of transgenic mice, J Biol Chem, 268 (1993) 11994-12002.

[36] H.M. van Wering, I.L. Huibregtse, S.M. van der Zwan, M.S. de Bie, L.N. Dowling, F. Boudreau, E.H. Rings, R.J. Grand, S.D. Krasinski, Physical interaction between GATA-5 and hepatocyte nuclear factor-1alpha results in synergistic activation of the human lactase-phlorizin hydrolase promoter, J Biol Chem, 277 (2002) 27659-27667.

[37] M. van der Sluis, A. Vincent, J. Bouma, A. Korteland-Van Male, J.B. van Goudoever, I.B. Renes, I. Van Seuningen, Forkhead box transcription factors Foxa1 and Foxa2 are important regulators of Muc2 mucin expression in intestinal epithelial cells, Biochem Biophys Res Commun, 369 (2008) 1108-1113.

[38] N. Jonckheere, A. Vincent, M. Perrais, M.P. Ducourouble, A.K. Male, J.P. Aubert, P. Pigny, K.L. Carraway, J.N. Freund, I.B. Renes, I. Van Seuningen, The human mucin MUC4 is transcriptionally regulated by caudal-related homeobox, hepatocyte nuclear factors, forkhead box A, and GATA endodermal transcription factors in epithelial cancer cells, J Biol Chem, 282 (2007) 22638-22650.

[39] E.E. Morrisey, H.S. Ip, M.M. Lu, M.S. Parmacek, GATA-6: a zinc finger transcription factor that is expressed in multiple cell lineages derived from lateral mesoderm, Dev Biol, 177 (1996) 309-322.

[40] A.C. Laverriere, C. MacNeill, C. Mueller, R.E. Poelmann, J.B. Burch, T. Evans, GATA-4/5/6, a subfamily of three transcription factors transcribed in developing heart and gut, J Biol Chem, 269 (1994) 23177-23184.

[41] F. Renaud, A. Vincent, C. Mariette, D. Buob, M. Crépin, S. Truant, M.C. Copin, N. Porchet, E. Leteurtre, I. Van Seuningen, M.P. Buisine, Etude du profil de méthylation des gènes de mucines dans les cancers colorectaux, Ann Pathol, 29 (2009) S150.

[42] K. Sumi, T. Tanaka, A. Uchida, K. Magoori, Y. Urashima, R. Ohashi, H. Ohguchi, M. Okamura, H. Kudo, K. Daigo, T. Maejima, N. Kojima, I. Sakakibara, S. Jiang, G. Hasegawa, I. Kim, T.F. Osborne, M. Naito, F.J. Gonzalez, T. Hamakubo, T. Kodama, J. Sakai, Cooperative interaction between hepatocyte nuclear factor 4 
alpha and GATA transcription factors regulates ATP-binding cassette sterol transporters ABCG5 and ABCG8, Mol Cell Biol, 27 (2007) 4248-4260.

[43] S.Z. Hasnain, C.M. Evans, M. Roy, A.L. Gallagher, K.N. Kindrachuk, L. Barron, B.F. Dickey, M.S. Wilson, T.A. Wynn, R.K. Grencis, D.J. Thornton, Muc5ac: a critical component mediating the rejection of enteric nematodes, J Exp Med, 208 (2011) 893-900. 


\section{Figure legends}

Figure 1: Expression of Muc5ac, GATA-6 and HNF-4 $\alpha$ transcription factors during stomach development of the mouse. PAS staining and IHC for Muc5ac, GATA-6 and HNF$4 \alpha$ were performed as described in the material and methods section on embryonic day (ED) 18.5 and adult stomach tissue. PAS and Muc5ac stainings were observed in embryonic stomach as of ED18.5 and expression was conserved in adult stomach. GATA-6 and HNF-4 $\alpha$ expression was induced in the stomach as of ED18.5 and expression increased after birth.

Figure 2: Regulation of Muc5ac promoter by HNF and GATA transcription factors. (A) Co-transfection experiments were performed in CMT-93 cells in the presence of $1 \mu \mathrm{g}$ of Muc5ac pGL3-deletion mutant $-3070 /+3$ (black bars) or -1021/+3 (grey bars) and $0.25 \mu$ g of the expression vector as indicated. Ref. refers to the normalized luciferase activity of the pGL3-deletion mutants of interest co-transfected with the corresponding empty expression vector. The data are displayed as averages of values obtained in triplicate in three separate experiments \pm standard error of the mean. Differences in the mean were analysed by the one way ANOVA test with selected comparison using tukey post-hoc test with differences less than 0.05 considered significant and were indicated with an $* * *$ indicates $\mathrm{p}<0.01$. Measurement of Muc5ac mRNA level by RT-PCR in CMT-93 cells transfected with either 2 $\mu \mathrm{g}$ of plasmid encoding GATA-4, GATA-5, GATA-6, HNF-1 $\alpha$, HNF-1 $\beta$, FOXA1, FOXA2, FOXA3, HNF-4 $\alpha$ and HNF-4 $\gamma$, expression vectors or corresponding empty vector (Ref.). The diagram represents the calculated ratio of Muc5ac/ $\beta$-actin. Standard deviation represents the means of values obtained from three separate experiments. (C) Study of the synergistic effects between GATA-6, HNF- $1 \alpha$ and HNF-4 $\alpha$ on the promoter activity of Muc5ac. Co-transfection experiments were performed in CMT-93 cells in the presence of $1 \mu \mathrm{g}$ of Muc5ac pGL3- 
deletion mutant $-1021 /+3$ and $0.125 \mu \mathrm{g}$ of the each expression vector as indicated. Ref. refers to normalized luciferase activity of the pGL3 plasmid with the corresponding empty vector. The data are displayed as average \pm standard error of the mean.

Figure 3: Identification of HNF and GATA cis-elements in the promoter of Muc5ac. (A) Identification of GATA and HNF cis-elements by EMSA. $8 \mu \mathrm{g}$ of nuclear extracts prepared from CMT-93 cells were incubated with the radiolabelled T127, T126 and T122 DNA probes (+, lanes 2, 7 and 14). Lanes 1-5, T127, GATA-binding site at -774/-771; lanes 6-12, T126, HNF binding site at -634/-630; lanes 13-22, T122, HNF binding site at -2614/-2610. Supershift experiments were carried out by adding $1 \mu \mathrm{l}$ of the antibody of interest : antiGATA-4 (lane 4), anti-GATA-6 (lane 5), anti-HNF-1 $\alpha$ (lane 10 and 17), anti-HNF-1 $\beta$ (lane 11 and 18), anti-FOXA1 (lane 19), anti-FOXA2 (lane 20), anti-HNF4- $\alpha$ (lane 12 and 21), anti-HNF-4 $\gamma$ (lane 22). Cold competitions were performed by preincubating the nuclear extracts with 100x excess of cold T127 (lane 3), cold T126 (lane 8), cold mutated T126 (lane 9), cold T122 (lane 15), and cold mutated T122 (lane 16) probes, respectively. Radiolabelled probe alone were loaded in the first lane of each series (lanes 1, 6 and 13). (B) Binding of GATA-4, -5 , and -6 to chromatin of CMT-93 cells by ChIP. PCRs were carried out with specific pairs of primers covering the -1019/-723 DNA region including T127. PCR products $(10 \mu \mathrm{l})$ were analyzed on $1.2 \%(\mathrm{w} / \mathrm{v})$ agarose gels. IgGs, negative control with rabbit IgGs. Input, positive control with total chromatin. (C) Binding of HNF-1 $\alpha$, HNF-1 $\beta$, HNF- $4 \alpha$, HNF- $4 \gamma$ to chromatin by ChIP. PCRs were carried out with specific pairs of primers covering -769/-544 (including T126) and -2904/-2608 (including T122) DNA regions.

Figure 4: Site-directed mutagenesis of HNF and GATA cis-elements in Muc5ac promoter. (A) Transient transfection experiments were performed in the presence of $1 \mu \mathrm{g}$ of 
T122 or T126 wild type (wt.) or mutated (mut.) forms of $-3070 /-1$ and $-1021 /-1$ Muc5ac promoter constructs, and $0.5 \mu \mathrm{g}$ of HNF- $1 \alpha$, HNF- $1 \beta$, HNF- $4 \alpha$, HNF- $4 \gamma$ expression vectors. (B) Transient transfection experiments were performed in the presence of $1 \mu \mathrm{g}$ of T127 wildtype (wt.) or mutated (mut.) forms of $-1021 /-1$ Muc5ac promoter constructs and $0.5 \mu \mathrm{g}$ of GATA-4, GATA-5 and GATA-6 expression vectors Results are expressed as fold activation of relative luciferase activity obtained when co-transfected with the expression vector encoding the TF of interest compared with cells transfected with corresponding empty vectors. The transactivating activity obtained with the corresponding empty vector was arbitrarily set to 1 . The data are displayed as averages of values obtained in triplicate in three separate experiments \pm standard error of the mean. ${ }^{*}, \mathrm{p}<0.05$.

Supplemental figure 1: Expression of Muc5ac mucin, GATA-6 and HNF-4 $\alpha$ transcription factors at PND 1.5. IHC for Muc5ac, GATA-6 and HNF-4 $\alpha$ was performed as described in the material and methods section on postnatal day (PND) 1.5 serial sections. Muc5ac, GATA-6 and HNF-4 $\alpha$ stainings were observed in gastric cell population of PND 1.5 mouse embryo.

Supplemental figure 2: HNF-4 $\alpha$, HNF-4 $\gamma$ and GATA-6 mRNA expression is not upregulated by HNF-1 $\alpha$, or HNF-1 $\beta$ transcription factors. HNF- $4 \alpha$, HNF- $4 \gamma$ and GATA-6 mRNA level were assessed by RT-PCR in CMT-93 cells transfected with either $2 \mu \mathrm{g}$ of plasmid encoding HNF- $1 \alpha$, or HNF- $1 \beta$ expression vectors or corresponding pSG5 empty vector. 
Figure 1: Jonckheere et al.

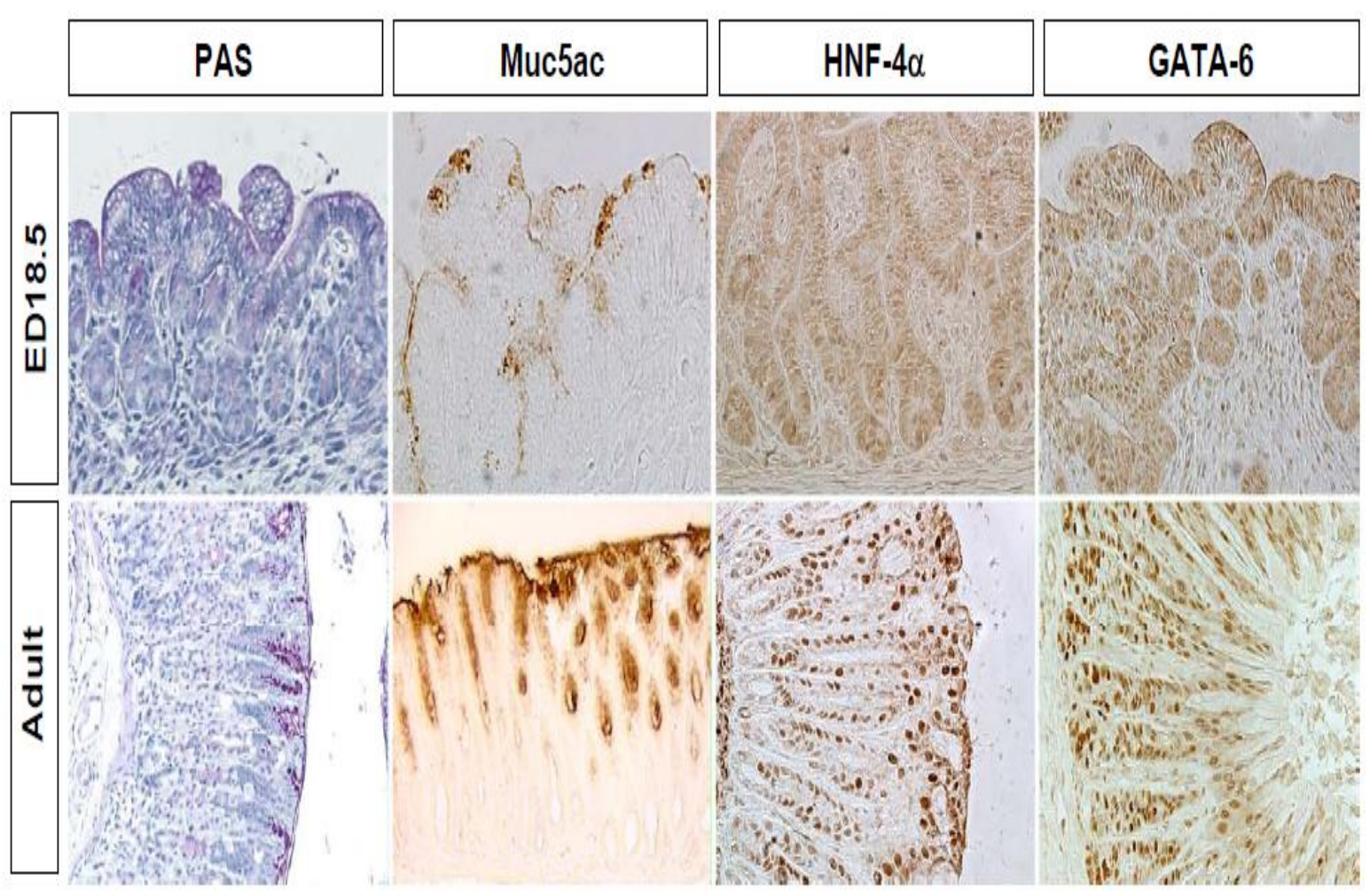


Figure 2 : Jonckheere et al.

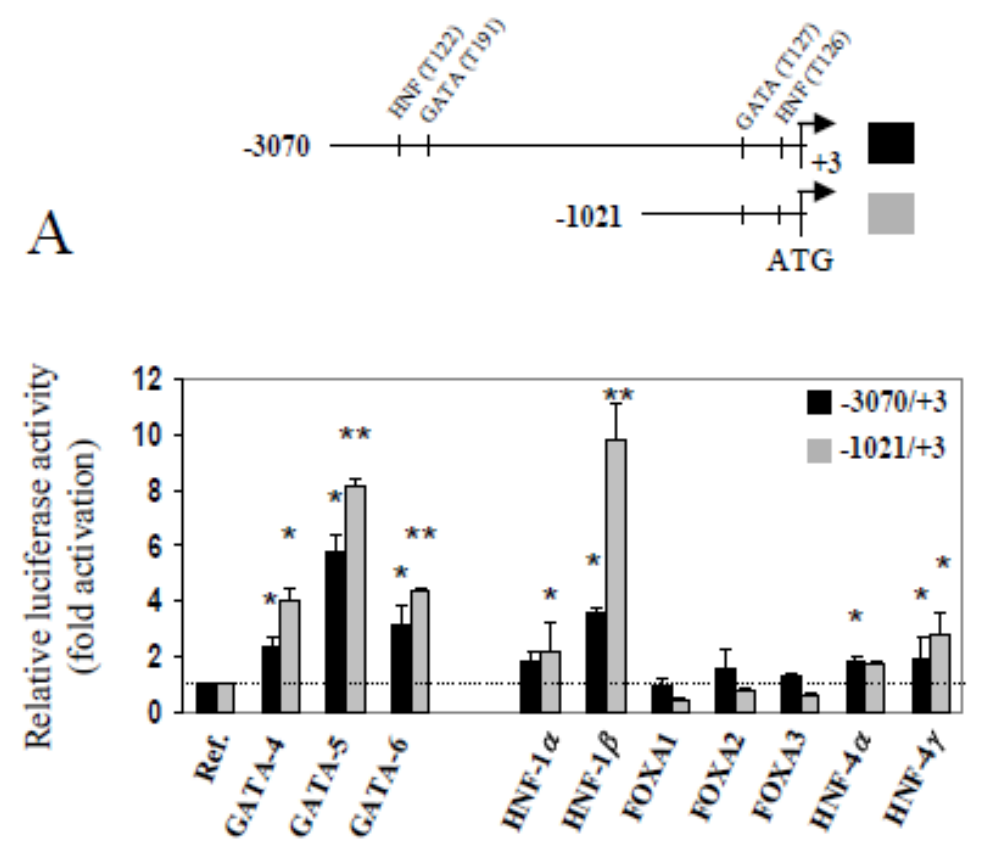

B

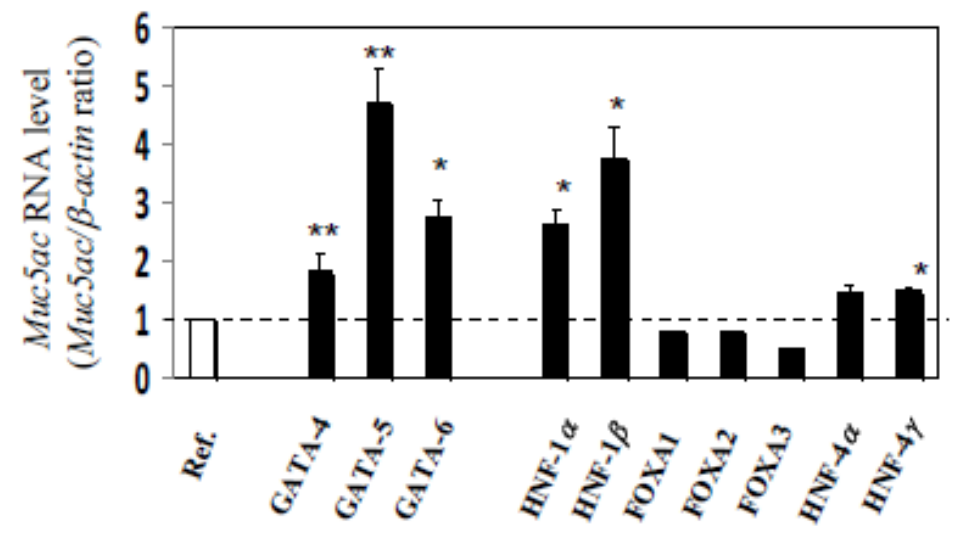

C

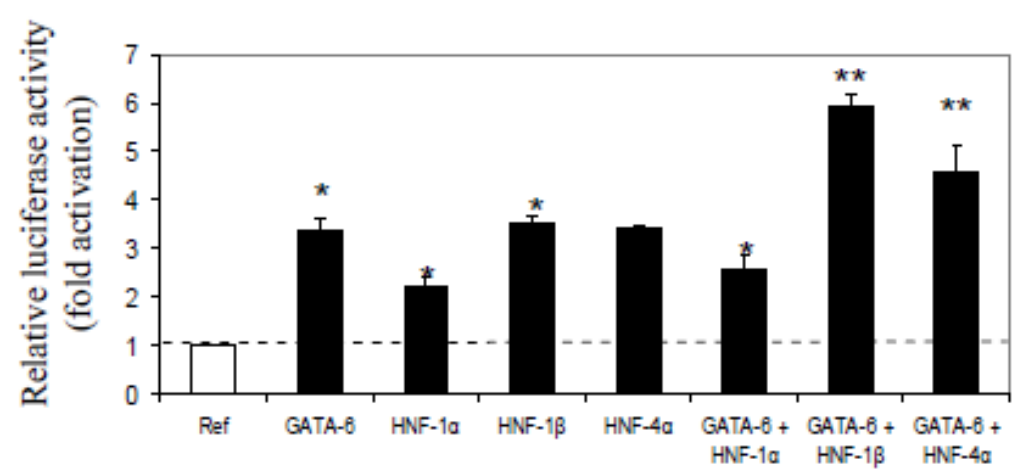


Figure 3 : Jonckheere et al.
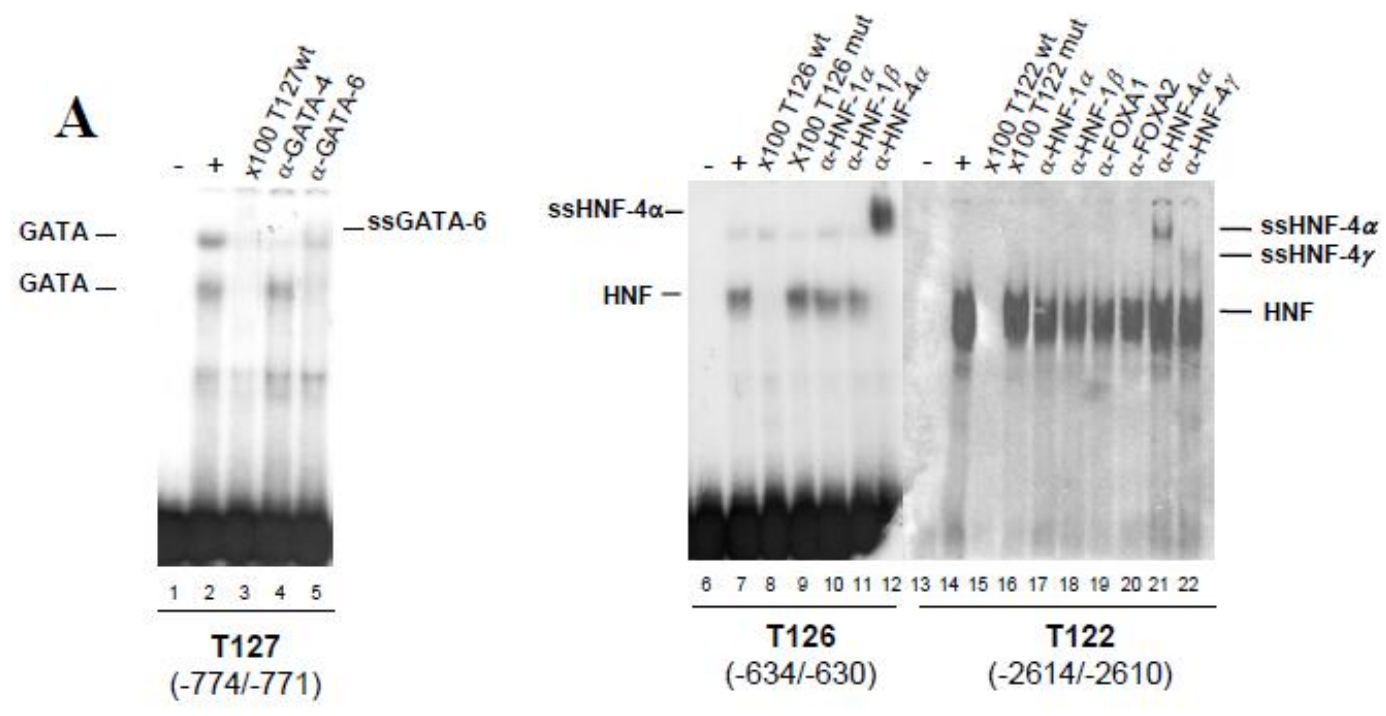

B
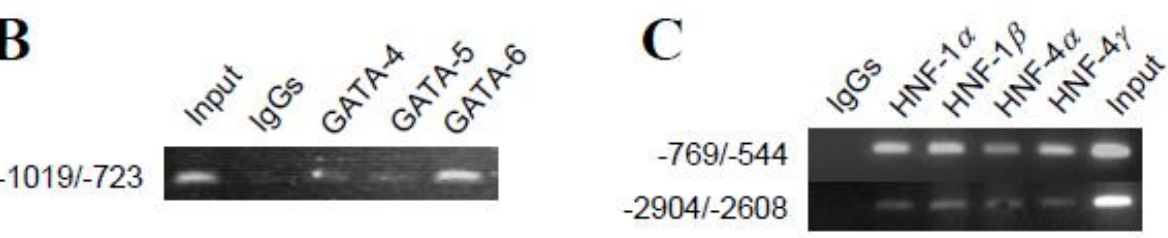
Figure 4 : Jonckheere et al.

A

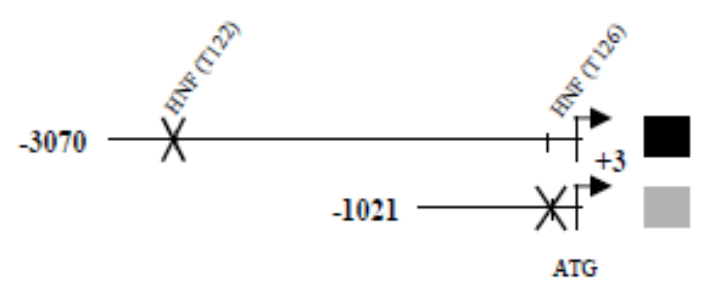

Х Site-directed mutagenesis of HNF cis-elements

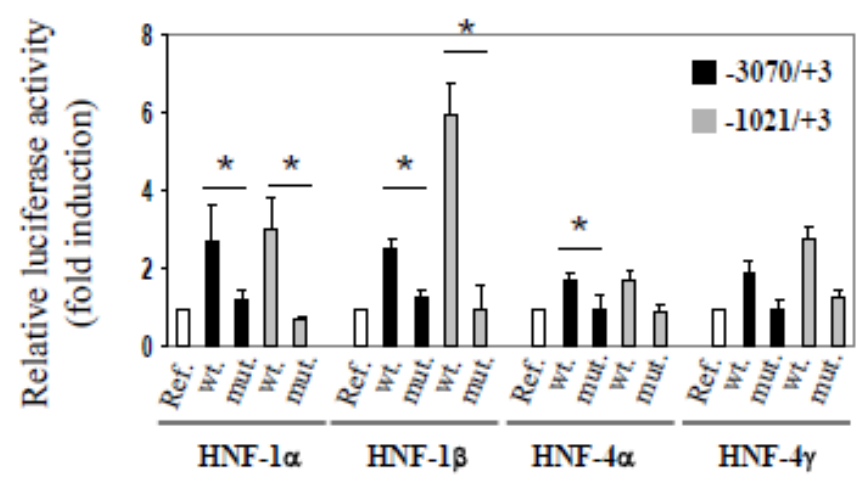

B
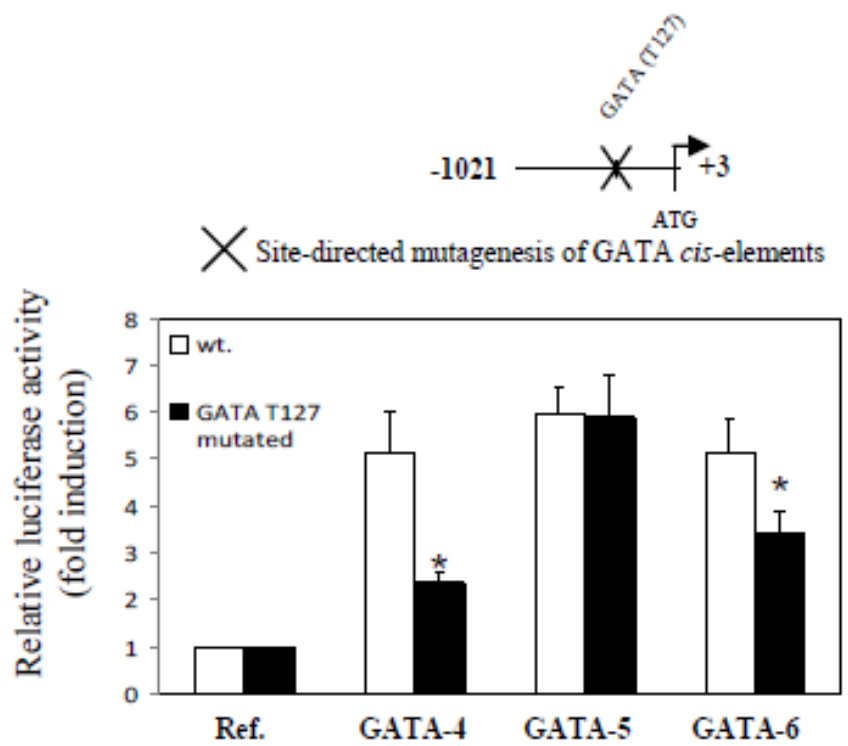
Table I : Sequences of the sense oligonucleotides used for EMSAs, ChIP and site-directed mutagenesis. For EMSA studies, antisense oligonucleotides were also synthesized and annealed to the sense oligonucleotides to produce double-stranded DNA. Mutated nucleotides are italicized and underlined. Positions of the putative binding sites in the promoter are indicated and are bold.

\begin{tabular}{|c|c|c|c|}
\hline \multicolumn{4}{|c|}{ Sequences of oligonucleotides for EMSA } \\
\hline Probe & \multicolumn{2}{|c|}{ Putative binding site } & Sequence $\left(5^{\prime} \rightarrow 3^{\prime}\right)$ \\
\hline T126 & \multicolumn{2}{|c|}{ HNF (-634/-630) } & CCTGGTCTGGGCAAAGGTCCATGC \\
\hline T164 & \multicolumn{2}{|c|}{ T126 mutated } & CCTGGTCTGGG $\underline{T C G T G T C C A T G C}$ \\
\hline T127 & \multicolumn{2}{|c|}{ GATA (-774/-771) } & CTCTCCCATGATAGGGTCCTT \\
\hline T187 & \multicolumn{2}{|c|}{ T127 mutated } & CTCTCCCAT $\underline{C T T A G G G T C C T T}$ \\
\hline T191 & \multicolumn{2}{|c|}{ GATA $(-2521 /-2518)$} & CCATTCACTTATCAGCTCCCA \\
\hline T122 & \multicolumn{2}{|c|}{ HNF (-2614/-2610) } & TATGGCCATGACCTTTGCCCTATA \\
\hline T159 & \multicolumn{2}{|c|}{ T122 mutated } & TATGGCCATGACC $\underline{G C G T G C C T A T A}$ \\
\hline \multicolumn{4}{|c|}{ Sequences of oligonucleotides for ChIP } \\
\hline \multicolumn{3}{|c|}{\begin{tabular}{|l|l} 
Amplified & TF binding site \\
DNA region &
\end{tabular}} & Sequence $\left(5^{\prime} \rightarrow 3^{\prime}\right)$ \\
\hline \multicolumn{2}{|c|}{$-1019 /-723$} & GATA T127 & $\begin{array}{l}\mathrm{F}: 5^{\prime} \text {-CACACACACACACACTCAACT-3' } \\
\mathrm{R}: \text { : 5'- CCAATGTCAGCAGCTCTGT-3' }\end{array}$ \\
\hline \multicolumn{2}{|c|}{$-2904 /-2608$} & HNF T122 & $\begin{array}{l}\text { F : 5' TAATCTCCACTGAGTCACCAG-3' } \\
\text { R : 5'-GGACTGGGTCTGGTCTGA-3' }\end{array}$ \\
\hline \multicolumn{2}{|c|}{$-769 /-544$} & HNF T126 & $\begin{array}{l}\text { F : 5'-GCTGCTGACATTGGCTGA-3' } \\
\text { R : 5'-GTCAGAAGCCAAAGCATT-3' }\end{array}$ \\
\hline
\end{tabular}




\begin{tabular}{|l|l|l|}
\hline \multicolumn{3}{|l|}{ Sequences of oligonucleotides for site-directed mutagenesis } \\
\hline HNF & T122 mutated & GAATATGGCCATGACC $\underline{C G T G C C T A T A C T G G T C C C T ~}$ \\
\hline HNF & T126 mutated & TCCCTGGTCTGGCC $\underline{C G C G G T C C A T G C A C G ~}$ \\
\hline GATA & T127 mutated & GCCTACCATCTCCCAT $\underline{C T T A G G G T C C T T C A T T C C ~}$ \\
\hline GATA & T191 mutated & CCAGATTGTAGTAAGCCATTCACTTAAGAGCTCCCA \\
& & AAAGG \\
\hline
\end{tabular}

Jonckheere et al., Supplemental figure 1

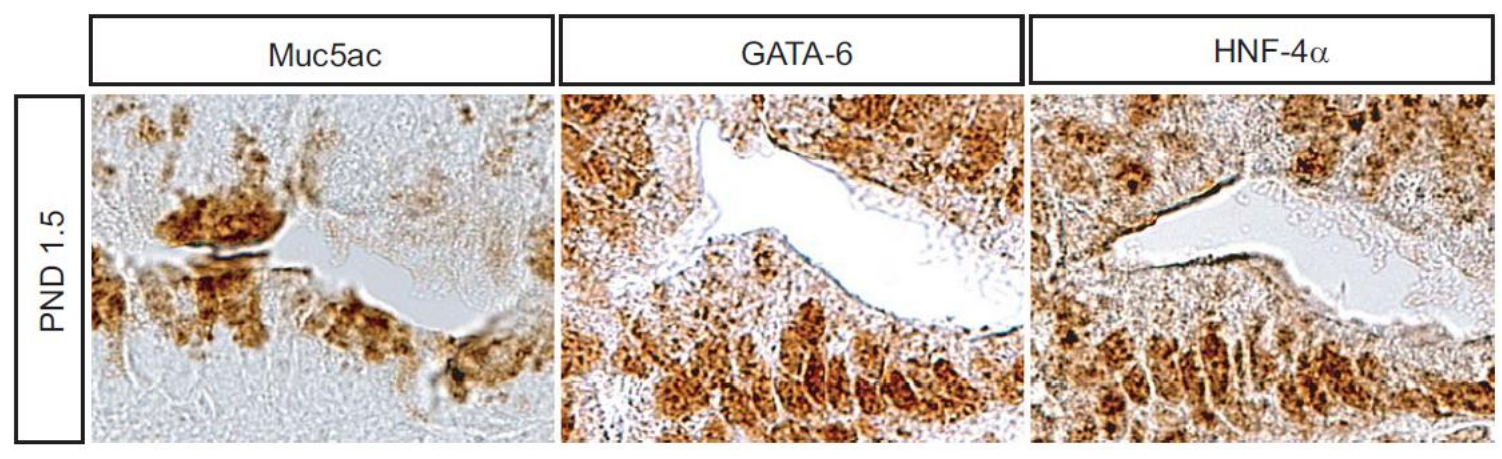




\section{Supplemental figure 2 : Jonckheere et al.}
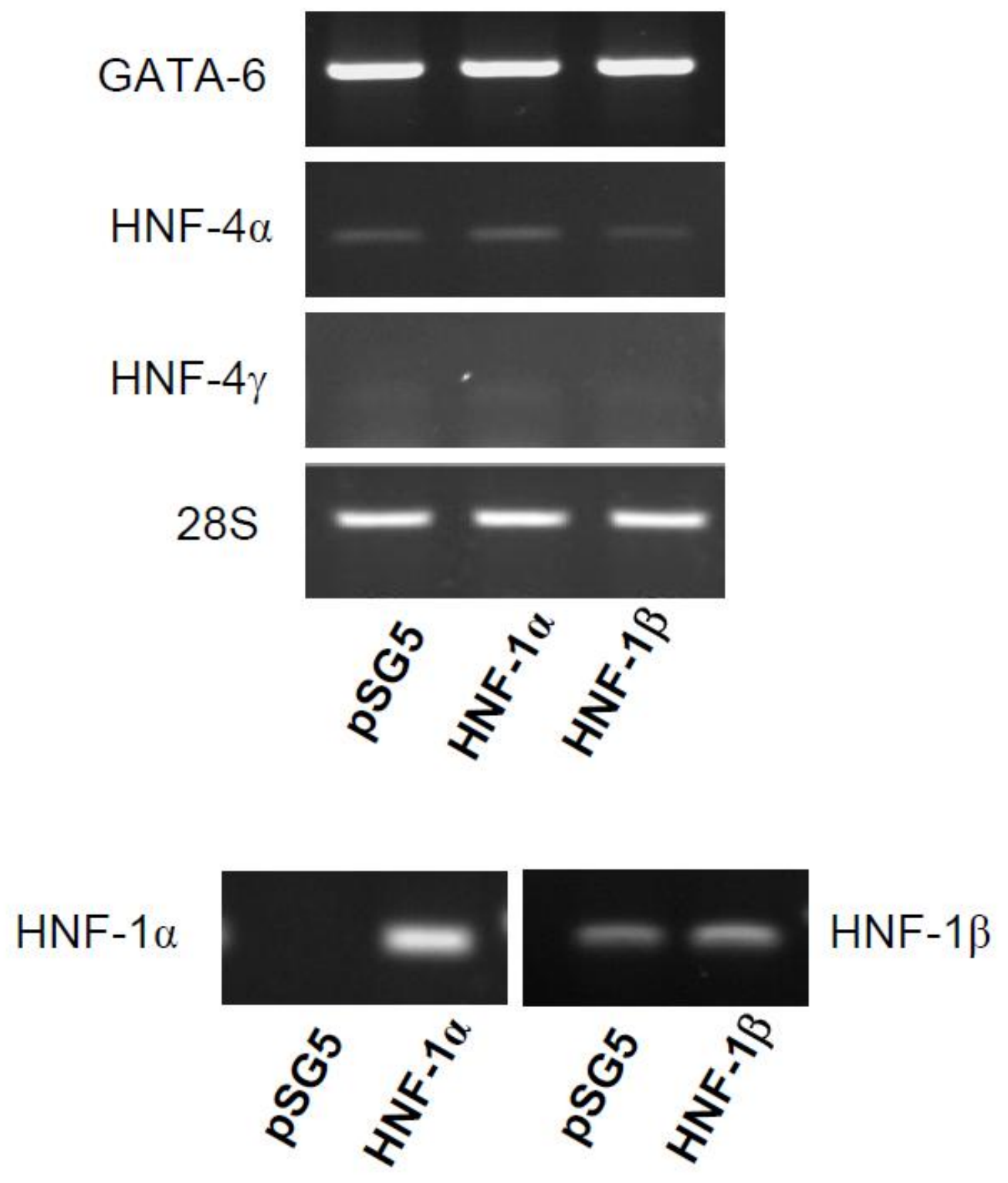

Highlights :

- Muc5ac, GATA-6 and HNF-4 $\alpha$ are expressed concomitantly in the developing mouse stomach

- GATA-4/-5/-6 and HNF-1 $\alpha /-1 \beta /-4 \alpha /-4 \gamma$ TF promote Muc5ac transcription

- Muc5ac promoter contains one active GATA cis-element. 
- Two active HNF cis-elements were identified within Muc5ac promoter

- HNF and GATA TF are regulators of Muc5ac mucin expression in the developing stomach 